Käck, Annika

\title{
Migrant teachers in Swedish teacher education and their re-entry as
} professionals

Kremsner, Gertraud [Hrsg.]; Proyer, Michelle [Hrsg.]; Biewer, Gottfried [Hrsg.]: Inklusion von Lehrkräften nach der Flucht. Über universitäre Ausbildung zum beruflichen Wiedereinstieg. Bad Heilbrunn : Verlag Julius Klinkhardt 2020, S. 197-201

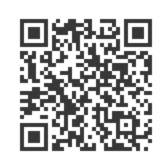

Quellenangabe/ Reference:

Käck, Annika: Migrant teachers in Swedish teacher education and their re-entry as professionals - In: Kremsner, Gertraud [Hrsg.]; Proyer, Michelle [Hrsg.]; Biewer, Gottfried [Hrsg.]: Inklusion von Lehrkräften nach der Flucht. Über universitäre Ausbildung zum beruflichen Wiedereinstieg. Bad

Heilbrunn : Verlag Julius Klinkhardt 2020, S. 197-201 - URN: urn:nbn:de:0111-pedocs-189252 - DOI: 10.25656/01:18925

https://nbn-resolving.org/urn:nbn:de:0111-pedocs-189252

https://doi.org/10.25656/01:18925

in Kooperation mit / in cooperation with:

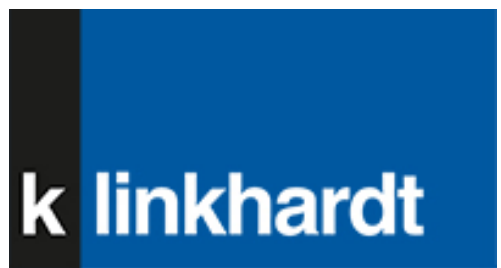

http://www.klinkhardt.de

\section{Nutzungsbedingungen}

Dieses Dokument steht unter folgender Creative Commons-Lizenz: http://creativecommons.org/licenses/by-nc-sa/4.0/deed.de - Sie dürfen das Werk bzw. den Inhalt unter folgenden Bedingungen vervielfältigen, verbreiten und öffentlich zugänglich machen sowie Abwandlungen und Bearbeitungen des Werkes bzw. Inhaltes anfertigen: Sie müssen den Namen des Autors/Rechteinhabers in der von ihm festgelegten Weise nennen. Dieses Werk bzw. der Inhalt darf nicht für kommerzielle Zwecke verwendet werden. Die neu entstandenen Werke bzw. Inhalte dürfen nur unter Verwendung von Die neu entstandenen Werke bzw. Inhalte dürfen nur unter Verwendung von
Lizenzbedingungen weitergegeben werden, die mit denen dieses Lizenzvertrages identisch oder vergleichbar sind.

Mit der Verwendung dieses Dokuments erkennen Sie die Nutzungsbedingungen an.

\section{Terms of use}

This document is published under following Creative Commons-License: http://creativecommons.org/licenses/by-nc-sa/4.0/deed.en - You may copy, distribute and transmit, adapt or exhibit the work in the public and alter, transform or change this work as long as you attribute the work in the manner specified by the author or licensor. You are not allowed to make commercial use of the work. If you alter, transform, or change this work in any way, you may distribute the resulting work only under this or a comparable license.

By using this particular document, you accept the above-stated conditions of use.

\section{Kontakt / Contact:}

peDOcs

DIPF | Leibniz-Institut für Bildungsforschung und Bildungsinformation

Informationszentrum (IZ) Bildung

E-Mail: pedocs@dipf.de

Internet: www.pedocs.de

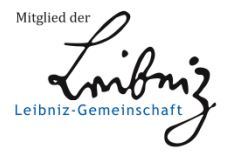




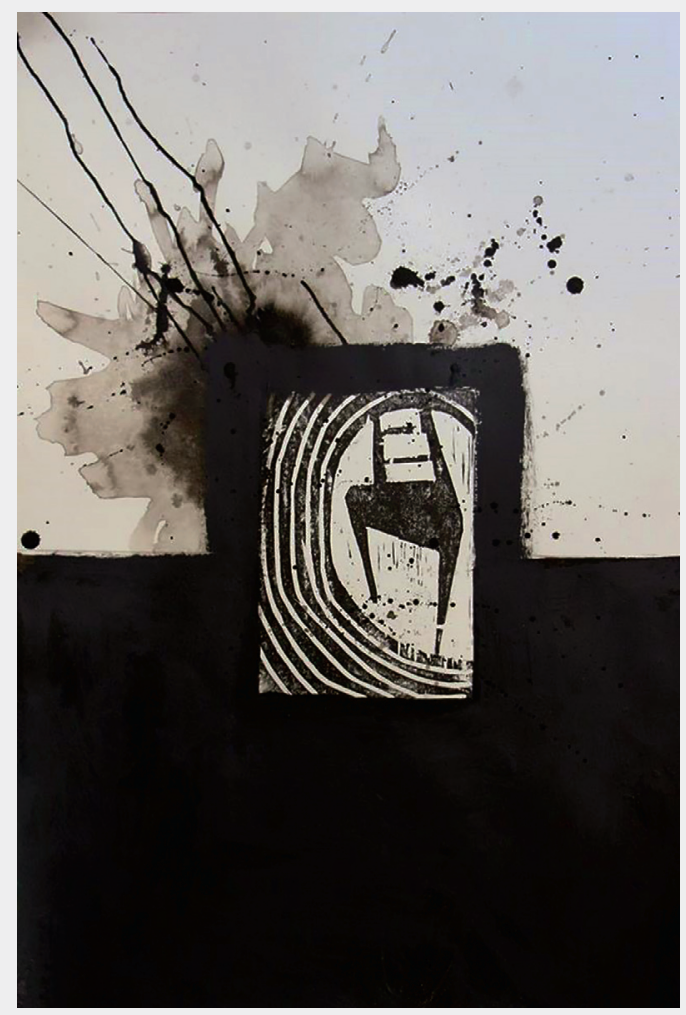

Gertraud Kremsner Michelle Proyer

Gottfried Biewer (Hrsg.)

Inklusion von Lehrkräften nach der Flucht

Über universitäre Ausbildung zum beruflichen Wiedereinstieg 


\section{Gertraud Kremsner Michelle Proyer Gottfried Biewer (Hrsg.)}

\section{Inklusion von Lehrkräften nach der Flucht}

Über universitäre Ausbildung zum beruflichen Wiedereinstieg 
„Allen Personen gewidmet, die geflïchtet sind, sich derzeit auf der Flucht befinden oder noch flïchten werden. "

Die Publikation des Buches und die Open Access-Veröffentlichung wurde vom Zentrum für Lehrer*innenbildung und vom Postgraduate Center der Universität Wien bezuschusst.

Dieser Titel wurde in das Programm des Verlages mittels eines Peer-Review-Verfahrens aufgenommen. Für weitere Informationen siehe www.klinkhardt.de.

Bibliografische Information der Deutschen Nationalbibliothek Die Deutsche Nationalbibliothek verzeichnet diese Publikation in der Deutschen Nationalbibliografie; detaillierte bibliografische Daten sind im Internet abrufbar über http://dnb.d-nb.de.

2020.ig. (C) by Julius Klinkhardt.

Satz: Tina Obermayr, Wien

Abbildung Umschlagseite 1: Marwa Sarah (Österreich/Syrien) - Black Hole

The painful fact for a refugee or a foreigner is that you will be always looking for a place to belong to, and you will never find it again you will become a foreigner everywhere you go, slowly you will change and do not fit anywhere. and there will always be a black hole. black hole.

Druck und Bindung: AZ Druck und Datentechnik, Kempten.

Printed in Germany 2020.

Gedruckt auf chlorfrei gebleichtem alterungsbeständigem Papier.

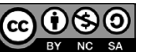

Die Publikation (mit Ausnahme aller Fotos, Grafiken und Abbildungen) ist veröffentlicht unter der Creative Commons-Lizenz: CC BY-NC-SA 4.0 International https://creativecommons.org/licenses/by-nc-sa/4.0/ 


\section{Inhaltsverzeichnis}

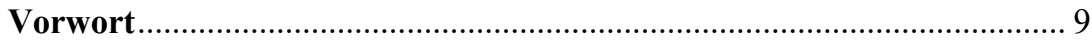

\section{Darstellungen und Forschungen zum Zertifikatskurs}

Gertraud Kremsner, Michelle Proyer und Tina Obermayr

Die Ausgangslage und die Einrichtung des Zertifikatskurses

„Bildungswissenschaftliche Grundlagen für

Lehrkräfte mit Fluchthintergrund“.

Gertraud Kremsner, Michelle Proyer und Alexander Schmölz mit Unterstützung von Helena Deiß, Lisa-Katharina Möhlen, Sarah Hofmann, Marwa Sarah und Tina Obermayr

Das Forschungsprojekt „Qualifizierung von Lehrkräften mit Fluchthintergrund“" 46

\section{Reflexion der Kursinhalte aus Sicht der Lehrenden}

Ines M. Breinbauer

Wie man in die Pädagogik einführen und dabei selber viel lernen kann!

Bildungswissenschaftliche Grundlagen in der Lehrer*innenbildung für Lehrpersonen mit Fluchthintergrund.

Regina Studener-Kuras

„Dass ich Lehrerin bin, das habe ich auf eine recht eigene Art ganz vergessen gehabt!" Lehren und Lernen im Kontext von Flucht und Neubeginn. 100

Michelle Proyer

,Ich male denen die Perspektive“ - Von Praxiserfahrungen zwischen ,bei uns‘ und ,bei euch', über das Erlernen von ,Reflexion“ und hin zu einem ,Ankommen` im österreichischen Schulsystem. 


\section{6 | Inhaltsverzeichnis}

Neda Forghani-Arani

Lived Experience of Teaching Displaced Teachers:

A Postcolonial Reading of Positions, Voices and Representations

Gottfried Biewer

„Inklusive Pädagogik und Vielfalt"

für Lehrkräfte mit Fluchthintergrund

Sabine Krause

Schulforschung und Unterrichtspraxis. Bewegungen zwischen

wissenschaftlicher Abstraktion und „Praxisrelevanz“

Raphael Zahnd und Gertraud Kremsner

Zur vertieften Auseinandersetzung mit Heterogenität in Schulkontexten... 134

Michael Doblmair und Michelle Proyer

Am Ende steht (wieder) die Reflexion

\section{Herausforderungen und Synergien}

Michelle Proyer, Gertraud Kremsner, Gottfried Biewer und Camilla Pellech

Herausforderungen und Synergien aus universitärer Perspektive

Linda Kreuter, Helena Deiß, Lisa-Katharina Möhlen, Kamal Alyouzbashi, Saad Chatto, Sahar Hashemi, Nizar Mousa, Doha Tahlawi, Ahmed Zeki Al Hamid und Jomard Rasul „Werden Träume wahr?“ - Reflexionen der Kursteilnehmer*innen

Marie-Claire Sowinetz

„Nehmen wir das Gute von uns und das Gute von euch so werden wir alle besser." Ein persönlicher Rückblick

auf den Beginn des Zertifikatskurses für geflüchtete Lehrer*innen 166

Katharina Resch

Vier Strategien zur Entwicklung von universitären

Weiterbildungsprogrammen im Bereich Flucht und Migration 
Renate Faistauer, Thomas Laimer und Nicola Kraml

Beitrag zu einer nachhaltigen Sprachförderung für Lehrende

mit Fluchthintergrund - Synergien in der Ausbildung schaffen

und Empowerment bei den Teilnehmer*innen ermöglichen.

Karoline Gerwisch, Denise Strehn, Nicolas Kieffer

und Michelle Proyer

Reflexion der Kurspraktika -

Perspektiven der Mentor*innen und Mentees 184

\section{Internationale Perspektiven}

Annika Käck

Migrant teachers in Swedish teacher education and their

re-entry as professionals

Susanna Malm

Bridging Programmes for Migrant Teachers

and Preschool Teachers in Sweden.

Henrike Terhart, Ariane Elshof und Susanne Preuschoff

Programm für geflüchtete Lehrkräfte an der Universität zu Köln.

Kristina Purrmann, Renate Schüssler, Christina Siebert-Husmann

und Marie Vanderbeke

„Wir haben so lange auf eine Chance gewartet“ -

Potentiale und Herausforderungen des Qualifizierungsprogrammes

Lehrkräfte Plus für geflüchtete Lehrkräfte

Katja Kansteiner, Roswitha Klepser, Sarah Lukas,

Kristin Rheinwald und Tim Kaiser

Integration geflüchteter Lehrkräfte in die Lehrer*innenausbildung in Baden-Württemberg - das IGEL-Programm.

Abschlussbemerkungen 


\section{Annika Käck}

\section{Migrant teachers in Swedish teacher education and their re-entry as professionals}

Teacher education has the task of preparing teachers for a professional role suitable within a national context but with respect to a global information society. In this chapter, research concerning migrant teachers with foreign teaching degrees studying Swedish teacher education is presented. Findings identify unfamiliar ways of thinking and practising they experienced in a new context. Further findings show what educated teachers experience when they re-enter as professionals in a new school context. Lastly, there will be some thoughts about further education and what content is needed in order to scaffold migrant teachers upon re-entering their profession.

\section{Cultural diversities and unfamiliar ways of thinking and practising}

Today, with increased migration and internationalisation, higher education faces challenges as the educational systems, and the way of thinking and practising within them, do not always match those of the international populations. Moloney and Saltmarsh (2016) report that there is a lack of acknowledgement for cultural diversities in teacher education programs. The prevailing approach is monocultural teaching. In higher education, there are unique traditions and practices concerning teaching and learning. These ways of thinking and practising have a strong influence on chosen teaching strategies and activities (cf. Kreber 2009; Hounsell \& Anderson 2009). University teachers teach the way they learned within a certain discipline, department, culture etc. Hence, it is of significant pedagogical importance to help students understand those ways of thinking and practising (cf. Meyer \& Land 2005; Meyer, Land \& Baillie 2010). Carroll and Ryan (2005) talk about shocks, the cultural and the academic. In the latter, students lose their knowledge about how to learn and do well. Cultural bias has been found in assessment methods, for example, penalising international students beyond the differences in ability levels. 


\section{Swedish education and migrant teachers}

Käck, Männikkö Barbutiu and Fors (2018b) conducted a study of migrant teachers, with former teaching degrees from 57 countries, studying at four Swedish teacher education programs. The aim was to identify what was experienced as unfamiliar during their studies. Both quantitative and qualitative data were collected and analysed, including a web survey completed by 228 respondents, 5 focus groups and 9 individual interviews with 34 migrant teachers, as well as 30 reflective texts written by 15 participants. The results identified cultural embeddedness in teacher education in relation to unfamiliar teaching and learning methods, learning environments, epistemological understanding, examination practices and the roles and expectations of society and education. For some of the migrant teachers, the similarities between the teacher education programs were obvious; others had unfamiliar ways of thinking and practising to deal with.

\subsection{Unfamiliar ways of thinking and practising in teacher education}

When migrant teachers come into Swedish teacher education, they are both educated teachers and student teachers at the same time. Expectations from both the teacher educator and the migrant teacher are culturally determined. There is a strong focus on the individual student in Sweden, with studentcentred, student-active learning, which some migrant teachers can find unsatisfying. Educating students who are so independent is, for some migrant teachers, a new way of teaching and learning that they must understand and become accustomed to. Furthermore, as a teacher educator in Sweden, one is more of a supervisor and mentor than an unapproachable, authoritative, central figure. The ways to acquire knowledge, as well as the design of teaching and learning could also be unfamiliar: for example, with digital environments, social-learning and group-work (some of them had never worked in groups), while others were familiar with the concepts. Being critical during education was considered problematic since some came from an educational system where this was not valued or promoted. Those migrant teachers explained that if a student was critical of the university teacher's teaching, the literature etc., they might receive a lower grade. In Swedish education, it is the opposite, and according to $\S 8$ and $\S 9$ in the Högskolelagen [Higher Education Act 1992:1434] (cf. Ministry of Education and Research 1992), the university education shall develop the student's ability to make independent and critical assessments, to critically reflect, in order to get a higher grade. Moreover, the examinations could be unfamiliar: blended examinations (oral, written, a variety of examinations during one course, group examinations) 
and process versus results (that the process is important, often equal to the final result). There is also additional knowledge concerning a teacher's work in Sweden that was unfamiliar, such as writing individual study plans, the close relationship between parents and teacher, in addition to some of the different norms and values in Sweden. Migrant teachers talked about a transformed teacher identity with additional skills. It is important to remember that migrant teachers are not a homogenous group and cannot be treated as such. The education they have in their former country can be quite like the Swedish one; however, for some, there are huge differences.

\subsection{The use of digital technology and media during the placement period}

The basic goal of professional development is to challenge teachers to reflect on their beliefs and practices. According to Lee and Schallert (2016), in order to understand yourself as a teacher, you must identify and coordinate your past, present and the targeted future self. Also, the practice of integrating and developing digital competence relates to beliefs, values and teacher change. During migrant teachers' placement period in Sweden, unfamiliar ways of thinking and practising were found regarding the curricula, pedagogical methods and in their role as teachers. Furthermore, unfamiliar use of digital technology and media was found, due to country-based reasons such as it was not demanded in the former country, it was forbidden, there was a lack of infrastructure, or it was not viewed as part of the practice. Other migrant teachers thought Sweden was behind their former country when it came to the pedagogical use of digital technology and media; it was well integrated into all subjects in their former country. There was a ranged knowledge base, from being digital illiterate to being a teacher in digital technology. The placement supervisor is of great importance in enhancing digital competence, being a role-model and motivator. Migrant teachers expressed that it was important to be digitally competent working as a teacher in a Swedish school, since digital technology and media is widely used (cf. Käck, Männikkö Barbutiu \& Fors 2018a).

\section{Migrant teachers re-entering as professionals after further education}

Bigestans (2015) focused on migrant teachers re-entering the professional sphere in Swedish schools. Twenty-one migrant teachers, as well as principals, colleagues, administrators and teacher educators, were interviewed. Moreover, five of the teachers were observed in the workplace. One challenge discovered included subject-specific vocabulary, everyday communica- 
tion, and bridging the academic language learned in teacher education between the two. Another challenge was the teacher's relationship with the students, which lacked the previous authoritative role. Occasionally the migrant teacher appeared less competent to parents and colleagues due to his or her Swedish language ability. Tension decreased if the school principal emphasised the recruitment as based on the assessment of the subject knowledge and teaching qualifications. The resources found included the migrant teachers setting limits in a way that positioned themselves as being someone to listen to, resisting being seen as less knowledgeable, and showing their professionalism (cf. Bigestans 2015). Seven migrant teachers' life stories about their professional practices in the Swedish school context, were investigated in a longitudinal study by Sandlund (2010). Migrant teachers construct, deconstruct and reconstruct their professional legitimacy in relation to the Swedish school. Since there was a struggle to gain legitimacy, several of them had to adopt a new professional approach. It was obvious that, when the school setting is uniform, there was no willingness to accept viewpoints or pedagogical insights from other school cultures. One conclusion is that identities not only pertain to private and personal qualities but also answers to contextual circumstances in the schools. In a study by Jönsson and $\mathrm{Ru}-$ benstein Reich (2006) the meeting of migrant teachers with the Swedish school culture, their construction of a new identity and what school leaders consider when recruiting to a multi-ethnic teachers' collegium were investigated. They interviewed 25 migrant teachers, and 11 school leaders (who also answered a survey). Migrant teachers used different strategies for coping with the new school context. The adaptation was the most common strategy, while others tried to create a hybrid between the old and the new. Lastly, some chose a confrontational strategy. School leaders in multi-cultural areas highlighted the benefits of hiring migrant teachers, seeing them as resources, role models and bridge builders. For school leaders in areas with fewer migrants, the ability to collaborate and having a consensus in teaching and learning was more important.

\section{Bridging the further education and the re-entry}

Further education can promote inclusion and integration, but only if intercultural aspects are identified and included in teaching and learning. During their education and their re-entry as professionals, migrant teachers process and construct a new teacher identity. This is a sensitive, emotional process, in which they transform competencies they already possess, make modifications, add new competencies or abandon some of the old ones. The goal is 
not to be a Swedish teacher, rather develop a new teacher identity with a strong knowledge base from a different educational system. Education is a creation of the past, present and predicted future, which makes the identification of ways of thinking and practising a process that must be carried out on a regular basis in order to enhance the quality and equality of teacher education so that it is suitable for the globalised 21 st century.

\section{References}

Bigestans, A. (2015): Utmaningar och möjligheter för utländska lärare som återinträder $i$ yrkeslivet $i$ svensk skola. [Challenges and possibilities for foreign teachers who reenter the professional sphere in the Swedish school]. Stockholm. Retrieved from: http://su.divaportal.org/smash/get/diva2:773560/FULLTEXT01.pdf [last access: 27.05.2019].

Carroll, J. \& Ryan, J. (2005): Teaching international students: Improving learning for all. London.

Hounsell, D. \& Anderson, C. (2009): Ways of thinking and practicing in biology and history: Disciplinary aspects of teaching and learning environments. In: Kreber, C. (Ed.): The University and its disciplines: Teaching and learning within and beyond disciplinary boundaries. New York, 69-83.

Jönsson, A. \& Rubenstein Reich, L. R. (2006): En yrkesidentitet i förändring? Invandrade lärares möte med den svenska skolan. [An occupational identity in transformation? Immigrant teachers meeting with the swedish school]. In: Pedagogisk Forskning $i$ Sverige, 11, issue number 2, 81-93.

Käck, A., Männikkö Barbutiu, S. \& Fors, U. (2018a): Migrant teachers' experiences with the use of digital technology and media during their placement period in Swedish schools. In: Heijnen, M., de Hei, M. \& van Ginkel, S. (Eds.): Proceedings of the ATEE Winter Conference: Technology and Innovative Learning 2018. Utrecht, Netherlands, 63-71.

Käck, A., Männikkö Barbutiu, S. \& Fors, U. (2018b): Unfamiliar ways of thinking and practising in teacher education: experiences by migrant teachers. In: Sablic, M., Skugor, A. \& Durdevic Babic, I. (Eds.): Proceedings of the 42nd ATEE Annual Conference 2017 in Dubrovnik, Croatia: Changing Perspectives and Approaches in Contemporary Teaching. Brussels, Belgium, 219-235.

Kreber, C. (Ed.) (2009): The university and its disciplines: Teaching and learning within and beyond disciplinary boundaries. New York.

Lee, S. \& Schallert, D. L. (2016): Becoming a teacher: Coordinating past, present, and future selves with perspectival understandings about teaching. In: Teaching and Teacher Education, $56,72-83$.

Meyer, J. H. \& Land, R. (2005): Threshold concepts and troublesome knowledge (2): Epistemological considerations and a conceptual framework for teaching and learning. In: Higher education, 49, issue number 3, 373-388.

Meyer, J., Land, R. \& Baillie, C. (Eds.) (2010): Threshold concepts and transformational learning. Rotterdam.

Ministry of Education and Research (1992): Högskolelagen. [Higher Education Act 1992:1434].

Moloney, R. \& Saltmarsh, D. (2016): 'Knowing Your Students' in the Culturally and Linguistically Diverse Classroom. In: Australian Journal of Teacher Education, 41, issue number 4, 5.

Sandlund, M. (2010): Lärare med utländsk bakgrund. Sju yrkeslivsberättelser om möten med nya skolsammanhang. [Immigrant Teachers: Seven Life Stories about Work in New School Contexts]. Linköping, Sweden. 